\title{
Gabapentin enacarbil - clinical efficacy in restless legs syndrome
}

This article was published in the following Dove Press journal:

Neuropsychiatric Disease and Treatment

2I April 2010

Number of times this article has been viewed

\author{
Pinky Agarwal' \\ Alida Griffith' \\ Henry R Costantino ${ }^{2}$ \\ Narendra Vaish ${ }^{3}$ \\ 'Booth Gardner Parkinson's Center, \\ Kirkland, WA, USA; ${ }^{2}$ Costantino \\ Consulting, Woodinville, WA, USA; \\ ${ }^{3}$ Kirkland, WA, USA
}

Correspondence: Narendra Vaish I30I 4 NE 137th PI Kirkland, WA 98034 , USA

Tel +l 425-242-0I32

Email nkvaish@hotmail.com

Pinky Agarwal

Evergreen Neuroscience Institute, Booth Gardner Parkinson's Center, Movement Disorders Center, 12039 NE I2th Street, Suite 300, Kirkland,WA 98034, USA Email pagarwal@evergreenhealthcare.org

\begin{abstract}
Restless legs syndrome (RLS) is a sleep-related movement disorder commonly involving an unpleasant urge to move the limbs, typically the legs. Dopaminergic agents represent the first-line therapy for RLS; however, long-term use of such drugs results in worsening symptoms due to "augmentation" or other adverse events. Gabapentin, an analog of the inhibitory neurotransmitter gamma-aminobutyric acid (GABA), is an anticonvulsant/analgesic agent. Gabapentin is only mildly effective in relieving RLS symptoms, perhaps a result of its poor absorption from the gastrointestinal (GI) tract. Gabapentin enacarbil is a prodrug of gabapentin specifically designed to enhance absorption via the GI tract, and hence provide improved circulating levels of gabapentin on metabolism. Clinical trials to date have demonstrated favorable safety and (compared to traditional gabapentin) improved pharmacokinetics and efficacy in treating RLS symptoms. Thus, gabapentin enacarbil may prove to be a useful drug in treating RLS. An application of gabapentin enacarbil for treatment of RLS is currently pending with FDA for approval.
\end{abstract}

Keywords: restless legs syndrome, gabapentin enacarbil, movement disorder

\section{Introduction}

Restless legs syndrome (RLS) is a common, distressing disease that affects a significant percentage of the adult population. In the US, $2 \%$ to $3 \%$ of the population experience clinically bothersome symptoms severe enough to warrant treatment. ${ }^{1-3}$ RLS is characterized by discomfort of the legs during rest or inactivity and involves an urge to move the legs to relieve the symptoms. It can occasionally also affect the arms. RLS symptoms are usually present or worsen in the evening. ${ }^{4}$ Because of the discomfort of the limbs during rest, RLS can reduce sleep quality, daily function, and overall quality of life. Several drugs are currently used to treat RLS: dopaminergic agents such as levodopa (in combination with carbidopa or benserazide), dopamine agonists (such as ropinirole, and pramipexole), and nondopaminergic medications such as gabapentin, clonazepam and oxycodone. ${ }^{5,6}$ Common side effects of these drugs are sedation, dizziness, fatigue, nausea, and vomiting.

Gabapentin is an anticonvulsant drug and is approved in the United States for the treatment of postherpetic neuralgia ${ }^{7}$ and partial seizures. ${ }^{7-10}$ Gabapentin has also been shown effective in improving RLS symptoms, reducing the frequency of periodic leg movements and improving sleep quality, suggesting a potential role in treating RLS. ${ }^{11-15}$ Gabapentin is not approved for the indication of RLS treatment, although it is often used off-label for this purpose. ${ }^{5,16,17}$ Additional placebo-controlled, double-blind clinical 
trials have also suggested potential uses of gabapentin in the treatment of painful neuropathies in patients with diabetes mellitus ${ }^{18}$ and anxiety disorders. ${ }^{19}$

However, gabapentin has inherent pharmacokinetic deficiencies that limit its clinical effectiveness: variable bioavailability and short half-life. In healthy volunteers as well as epilepsy patients, clinical pharmacokinetic studies demonstrate limited absorption and high inter-patient variability. ${ }^{20-23}$ Bioavailability of orally administered gabapentin is dose-dependent. Surprisingly, bioavailability actually decreases with increasing dosages. Specifically, the oral bioavailability of gabapentin is approximately $60 \%$, $47 \%, 34 \%, 33 \%$, and $27 \%$ following 900, 1200, 2400, 3600, and $4800 \mathrm{mg} /$ day given in 3 divided doses, respectively. ${ }^{24}$ Importantly, the range of doses where bioavailability decreases coincides with doses reported to be useful to treat neuropathic pain. ${ }^{20}$

Saturation of the gabapentin transport pathway may account for the observed dose-dependent decrease in bioavailability. Absorption of gabapentin is mediated by a low-capacity solute transporter, probably an L-type amino acid transporter, which is located mainly in the upper small intestine. ${ }^{25,26}$ It has been suggested that the high inter-patient variability due to non-responders in clinical trials ${ }^{18,27}$ could be because of lower abundance of transporters in these patients, ${ }^{28}$ resulting in unpredictable plasma levels of gabapentin that may not reach therapeutically meaningful levels.

Gabapentin has a short half-life of just 5 to 7 hours. After oral administration and absorption, gabapentin is rapidly excreted via urine; therefore gabapentin must be dosed 3 to 4 times a day to maintain therapeutic levels. The requirement of frequent administration can lead to noncompliance and missed doses which can reduce clinical effectiveness. ${ }^{29}$

Enhancing the effectiveness of gabapentin has long been a goal, and pregabalin was developed in this direction. Pregabalin is a structural analog of gabapentin, which does not bind to gamma-aminobutyric acid (GABA) receptors, and is approved as an add-on medication for epilepsy and neuropathic pain. In a small clinical trial, pregabalin was efficacious in treating primary RLS as well as secondary RLS, and further investigation with randomized, placebocontrolled trials was recommended. ${ }^{30}$

In an attempt to address the pharmacokinetic limitations of gabapentin, Cundy and coworkers at Xenoport Inc. designed and synthesized a series of analogs of gabapentin and selected one candidate for further development based on its physico-chemical properties, enzymatic stability, transport, and in vivo pharmacokinetics. This compound was designated as gabapentin enacarbil or XP13512 28 (Figure 1). XP13512 is being further developed by XenoPort Inc/Astellas Pharma/ GlaxoSmithKline. A New Drug Application (NDA) has been filed with the Food and Drug Administration (FDA) and the current Prescription Drug User Fee Act (PDUFA) goal date for its review is February 2010.

\section{Drug design}

Gabapentin enacarbil (XP13512) is a gabapentin prodrug. Specifically, it is an acyloxyalkylcarbamate analog with an efficient enzymatic conversion to gabapentin in tissues. In addition, gabapentin enacarabil is designed to be recognized as a substrate for two high-capacity nutrient transporters with broad distribution through the human intestinal tract. One of the two transporters, monocarboxylate transporter type I (MCT-1), regulates the absorption of small-chain fatty acids and may transport pharmaceutical agents across the intestine. ${ }^{31}$ The second transporter is a sodium-dependent multivitamin transporter (SMVT). SMVT regulates absorption of the essential cofactors biotin, lipoate and pantothenate. ${ }^{32}$

\section{Pharmacology}

Gabapentin enacarbil is administered as an oral formulation. The pharmacology was evaluated as immediate-release (IR) and extended release (XR) formulations. ${ }^{33,34}$

\section{Improved bioavailability}

Gabapentin enacarbil is rapidly absorbed and undergoes efficient enzymatic hydrolysis to yield gabapentin in vivo. In contrast to gabapentin, which uses lower capacity transport receptors located only in the upper intestinal area, gabapentin enacarbil uses alternative, higher-capacity transport receptors found across the whole length of the gastrointestinal tract. Increased transport capacity allows the delivery of higher doses of gabapentin in good dose proportionality, avoiding uptake saturation at clinically relevant doses.

No saturation of transport was observed in a dose escalation study up to $2800 \mathrm{mg}$ using immediate release formulation; the plasma concentration of gabapentin was observed to increase proportionally in accordance with an orally administered dose of gabapentin enacarbil. ${ }^{33}$ In contrast, gabapentin transport was saturated at $1400 \mathrm{mg}$ oral dose levels. In the same study, similar observations were made with extended release tablet formulations of gabapentin enacarbil, with no sign of transport saturation up to $2100 \mathrm{mg}$ oral dose levels.

Improved oral bioavailability for gabapentin enacarbil compared to gabapentin has been demonstrated in animal and human pharmacokinetic studies. Cundy et $\mathrm{al}^{35}$ reported 

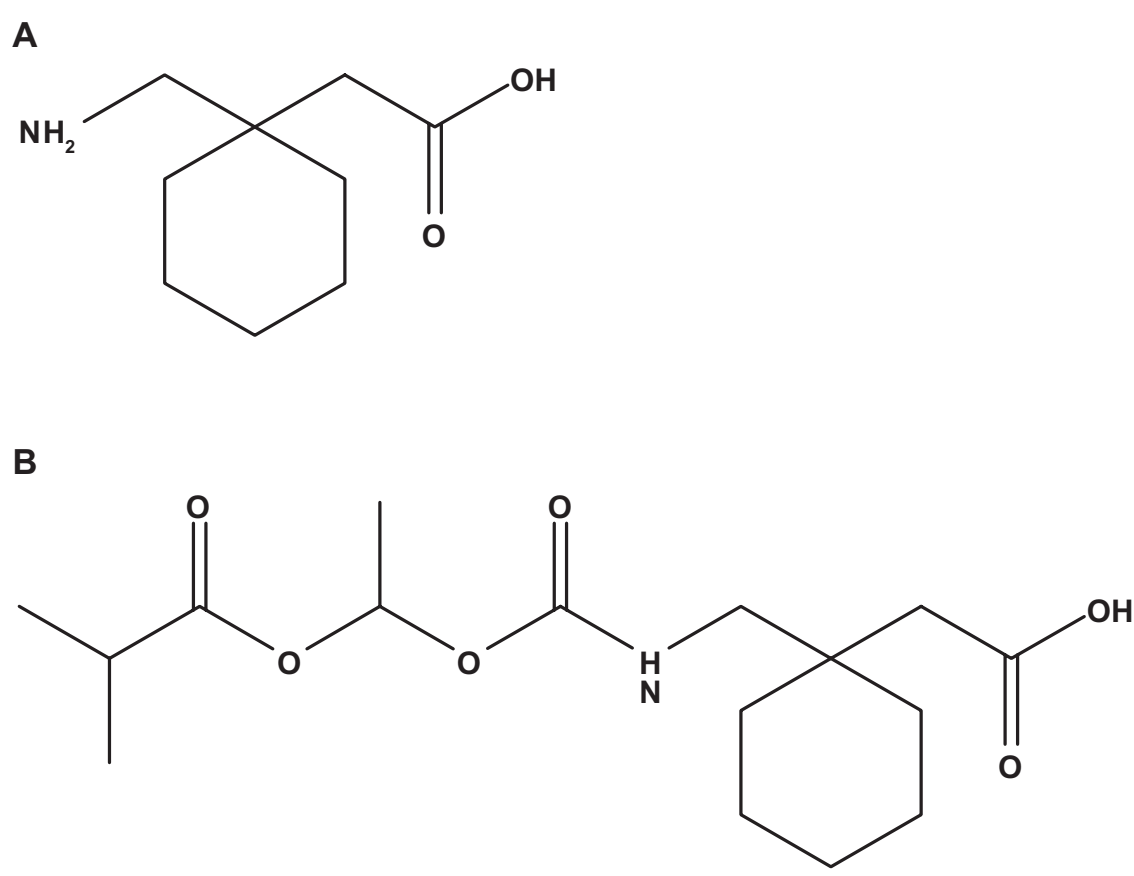

Figure I Chemical structures of A) gabapentin and B) gabapentin enacarbil.

improved oral bioavailability, dose proportionality, and colonic absorption for the prodrug compared to gabapentin in rats and monkeys. Compared with intracolonic gabapentin, intracolonic gabapentin enacarbil exhibited a 17-fold and 34-fold higher exposure in rats and monkeys, respectively. In addition, in monkeys, gabapentin enacarbil capsules resulted in $84.2 \%$ oral bioavailability compared with $25.4 \%$ bioavailability after a similar oral gabapentin dose. Importantly, this improvement in bioavailability was also observed in a human study, specifically, it was reported that the oral bioavailability of gabapentin enacarbil compared to gabapentin was $74.5 \%$ vs $36.6 \% .^{33}$ Based on the molecular weights and milligram-equivalent of gabapentin relative to the gabapentin enacarbil, a $365 \mathrm{mg}$ dose of gabapentin as prodrug $(700 \mathrm{mg})$ achieved higher or comparable plasma concentrations of gabapentin compared to a 1200 to $1400 \mathrm{mg}$ dose of free gabapentin in immediate release formulation. ${ }^{33}$ Efficient oral absorption of gabapentin enacarbil and conversion to achieve higher and dose-dependent concentration of gabapentin in plasma will allow preparation of longer-acting extended release formulations.

\section{Mode of action}

After intestinal absorption, gabapentin enacarbil is rapidly converted to gabapentin and the latter is the active form. Although gabapentin is well established as an effective antiepileptic and antineuropathic pain drug, the underlying molecular mechanism of gabapentin is still not entirely clear. ${ }^{36}$ Gabapentin is a structural analog of GABA; however gabapentin does not interact significantly with any GABA subtype receptors, ${ }^{37,38}$ for instance, several studies reported no evidence that gabapentin binds substantially to any subtype of $\mathrm{GABA}_{\mathrm{B}}$ receptors. ${ }^{37,39,40}$ Even so, one study suggested that gabapentin acts as an agonist for a subset of $\mathrm{GABA}_{\mathrm{B}}$ receptors ${ }^{41}$ which may negatively regulate voltage-gated $\mathrm{Ca}^{2+}$ channels ${ }^{42}$ and activate inwardly rectifying $\mathrm{K}^{+}$channels. ${ }^{43}$ Gabapentin has shown a direct effect on the excitability of sensory neurons by blockade of $\mathrm{Ca}^{2+}$ and $\mathrm{Na}^{+}$channels or activation of $\mathrm{K}^{+}$channels. ${ }^{44}$ Lee and coworkers demonstrated that gabapentin upregulated renal outer medullary potassium channel, thus reducing neuronal excitability, suggestive of an important role in gabapentin's antiepileptic effect. ${ }^{45}$

D-serine, an agonist for N-methyl-D-aspartate (NMDA) receptors, reverses some of gabapentin's actions. ${ }^{46}$ However, gabapentin does not directly interact with the glycine-NMDA complex, ${ }^{37,47}$ and a rat study concluded that D-serine and gabapentin do not act at the same site. ${ }^{48}$ Gabapentin also exhibits a profound synergistic anti-allodynic action with the AMPA receptor antagonist 6-cyano-7-nitroquinoxaline-2,3-dione (CNQX). ${ }^{49}$ A recent study concluded that after peripheral nerve injury, gabapentin acts directly in the brainstem via a glutamate-dependent mechanism to stimulate descending inhibition to produce antihypersensitivity. ${ }^{50}$ 
Suman-Chauhan and coworkers identified a high-affinity binding site for gabapentin in rat brain homogenate. ${ }^{38}$ Binding to this receptor was dependent on the system $\mathrm{L}$ transporter, indicating that gabapentin likely crosses the cell membrane and binding occurs intracellularly. There is no clear relationship between system $L$ transporter binding and clinical efficacy of gabapentin. ${ }^{51}$ The binding site for gabapentin was subsequently identified as the $\alpha_{2} \delta$ subunit of voltage-gated $\mathrm{Ca}^{2+}$ channel using pig cerebral cortex membranes. ${ }^{52}$ Hendrich and coworkers provided a definitive proof that gabapentin acts primarily at an intracellular location. ${ }^{53}$

\section{Pharmacokinetics, safety and tolerability}

Preclinical studies were conducted to establish the efficiency and conversion rate of gabapentin enacarbil to gabapentin in various tissues. Gabapentin enacarbil was chemically stable at physiological $\mathrm{pH}$ range as indicated by $>95 \%$ recovery of the prodrug after incubation for 1 hour at $37^{\circ} \mathrm{C}$ in buffers over the $\mathrm{pH}$ range of 2 to $8 .{ }^{28}$ However, the prodrug was rapidly converted to gabapentin by non-specific esterases in intestinal and liver tissues from rats, dogs, monkeys, and humans. Rates of conversion to gabapentin in human intestinal and liver tissue preparations at $1 \mathrm{mg}$ protein/mL were 196 and $146 \mathrm{pmol} /$ $\mathrm{min} / \mathrm{mg}$ protein. Similar rates of conversion were observed in rats and monkeys. After 1 hour of incubation at $37^{\circ} \mathrm{C}$ in tissue preparations of pancreatin, Caco- 2 cells, rat plasma, human plasma, rat liver, and human liver, 52\%, 18\%, 47\%, $96 \%, 25 \%$, and $4 \%$ of gabapentin enacarbil was recovered with release rates of gabapentin of $43 \%, 75 \%, 45 \%, 5 \%, 71 \%$, and $81 \%$, respectively. ${ }^{28}$ The conversion to gabapentin was quantitative in these studies and no formation of gabapentin lactam was observed. Both isomers of gabapentin enacarbil showed similar cleavage rates in human tissues. Gabapentin enacarbil also did not show substrate or inhibitor properties for major P450 isoforms in human liver homogenates. ${ }^{28}$ Therefore, gabapentin enacarbil is likely to have significantly low drug-drug interaction following administration.

To understand the mechanism of transport, in vitro transport studies across artificial lipid membranes were carried out. Gabapentin enacarbil showed pH-dependent passive permeability across the membrane suggesting that the prodrug should have some ability to passively diffuse across cells. ${ }^{28}$ However, passive diffusion is likely a minor component because $\mathrm{pKa}$ of gabapentin enacarbil is 5.0. Using in vitro cell culture assays, the transport of gabapentin enacarbil was shown to be dependent on MCT-1 and SMVT.
To understand the biodistribution and oral bioavailability, pharmacokinetic studies were performed in rats and monkeys. A dose-proportional exposure to gabapentin was observed after oral administration of gabapentin enacarbil, while exposure to the intact prodrug was low. More than $95 \%$ of radio labeled $\left[{ }^{14} \mathrm{C}\right]$-gabapentin enacarbil was excreted as gabapentin in urine in rats. In monkeys $84.2 \%$ of gabapentin enacarbil was excreted as gabapentin compared to $25.4 \%$ when gabapentin was delivered orally. Less than $1 \%$ of the intact prodrug was recovered in feces. ${ }^{53}$ In healthy human subjects, using supratherapeutic doses gabapentin enacarbil was converted rapidly to gabapentin after absorption. Blood levels of gabapentin were proportional to gabapentin enacarbil dose over the range of 2400 to $6000 \mathrm{mg}$ (1250-3125 mgequivalent gabapentin). Blood concentrations of intact gabapentin enacarbil were low and transient $(\leq 0.5 \%$ of the released gabapentin concentration at all doses). ${ }^{35}$ These studies indicate that gabapentin enacarbil is readily absorbed after oral delivery.

In addition to one molecule of gabapentin, hydrolysis of gabapentin enacarbil also produces one molecule each of carbon dioxide, acetaldehyde, and isobutyric acid. Both acetaldehyde and isobutyric acid are generally regarded as safe (GRAS) molecules by the FDA. Given that gabapentin enacarbil is converted into gabapentin, with a known safety profile, and also converted into GRAS compounds, it is likely that gabapentin enacarbil should exhibit a favorable safety profile. Consistent with this hypothesis, no significant toxicities were observed with gabapentin enacarbil in monkeys following repeated oral administration of $2000 \mathrm{mg} /$ $\mathrm{kg}$ /day doses. In addition no detectable accumulation was observed after 2 weeks. ${ }^{35}$

In a randomized-sequence, double-blind, placebocontrolled crossover study in healthy human subjects, gabapentin enacarbil was well tolerated up to supratherapeutic doses. ${ }^{54}$ In this study $600 \mathrm{mg}$ extended-release tablets of gabapentin enacarbil were administered as a single oral dose of $2400,3600,4800$, or $6000 \mathrm{mg}$. In a 32 healthy volunteer study, the most commonly reported adverse events were dizziness and nausea (50\% and $25 \%$ of subjects, respectively). Two subjects experienced treatment-emergent adverse events rated as severe: psychomotor retardation, vertigo, and sedation (4800 $\mathrm{mg}$ dose) and somnolence (6000 mg dose). All treatment-emergent adverse events were resolved without medical intervention. None of the adverse events led to study withdrawal. These data support that gabapentin enacarbil is safe and well tolerated with minimal side effects. 
To study the bioavailability of gabapentin enacarbil from immediate release formulation, pharmacokinetic studies were conducted in healthy volunteers in phase I clinical trials. ${ }^{34,55-57}$ Single doses of IR gabapentin enacarbil (350, 700, 1400, 2100 , and $2800 \mathrm{mg}$ orally; $\mathrm{n}=40)$ or placebo $(\mathrm{n}=10)$ were evaluated. After 1 week, approximately equimolar doses of gabapentin $(200,800,1200$, and $1400 \mathrm{mg})$ were given to participants. Gabapentin exposure with prodrug was doseproportional; bioavailability was $82.9 \%$ for the $350 \mathrm{mg}$ dose and $79.7 \%$ for the $2800 \mathrm{mg}$ dose. In contrast, with gabapentin parent the bioavailability was $65.2 \%$ and $26.5 \%$ with the lowest and the highest doses respectively. Multiple doses of gabapentin enacarbil (350, 400, 800, 1200 and $1400 \mathrm{mg}$ orally; twice daily, $n=29$ ), administered over 7 days, resulted in dose-proportional gabapentin. The bioavailability of gabapentin ranged from $73.1 \%$ to $93.2 \%$.

Bioavailability from sustained release formulation of gabapentin enacarbil (1200 mg orally) was evaluated either with $(n=10)$ or without food $(n=12)$. Gabapentin $(600 \mathrm{mg}$ orally; $\mathrm{n}=11)$ taken without food served as a reference. Exposure to gabapentin from gabapentin enacarbil was higher in the with food group compared to the fasted group. Exposure to gabapentin was higher in prodrug groups than the gabapentin group. Bioavailability of gabapentin was $46.5 \%$ and $73.7 \%$ for the fasted and fed gabapentin enacarbil groups respectively, while the bioavailability was $37.7 \%$ in parent drug group. ${ }^{58}$

The effect of fat content in food on gabapentin enacarbil absorption was evaluated under fasted, low-fat (200-300 kcal, $6 \%$ from fat), moderate-fat (500-600 kcal, 30\% from fat), and high-fat (1000 kcal, 50\% from fat) conditions. The different fat contents did not appear to affect the absorption of the prodrug. The bioavailability of gabapentin was $42 \%$, $64 \%, 65 \%$, and $76 \%$ in fasted, low-, medium-, and high-fat food conditions respectively. ${ }^{34}$

Potential for drug interactions between gabapentin enacarbil, naproxen (an MCT-1 substrate) and cimetidine (an organic cation transporter 2 substrate) was evaluated to assess the alterations in drug absorption when the prodrug is used in combination with these and other transporter substrates. In healthy volunteers, gabapentin enacarbil did not affect the bioavailability of naproxen or cimetidine. The AUC values of gabapentin enacarbil, when co-administered in combination with naproxen or cimetidine, increased up to $12 \%$ and $24 \%$, respectively. The results indicate that gabapentin enacarbil can be used together with MCT-1, organic cation transporter 2 , or other transporter substrates without the need to alter the dose regimes. ${ }^{59,60}$

\section{Efficacy}

Efficacy of gabapentin enacarbil was evaluated in several phase II and phase III trials. Because various phase I, II and III trials were recently summarized by Merlino et al $2009,{ }^{34}$ this review will focus on key phase II and III studies in conjunction with drug efficacy. Readers are encouraged to refer the review by Merlino et al for a summary of clinical trials prior to the publication of this article.

Efficacy of gabapentin enacarbil in relieving RLS symptoms was evaluated over a two week period in a multicenter, randomized, double-blind, placebo-controlled, crossover, polysomnographic phase IIa clinical trial in RLS patients. Patients were treated for two weeks with either gabapentin enacarbil (600 mg orally at 5 PM and $1200 \mathrm{mg}$ orally 1 hour before bed) or placebo, with a 1-week washout period between treatments. At the end of the treatment period, a significant improvement was observed in RLS symptoms such as quality of sleep, number of awakenings per night and hours awake per night. Compared to $14.7 \%$ patients reporting improvement of RLS symptoms in placebo group, $79.5 \%$ of patients in the gabapentin enacarbil group reported either much improved or very much improved symptoms. ${ }^{61}$ Efficacy and tolerability of $1800 \mathrm{mg}$ dose of gabapentin enacarbil was evaluated in 38 naïve subjects with RLS, over 9 clinical sites. ${ }^{62}$ Patients were treated with $1800 \mathrm{mg} /$ day for 14 days, with a 7-day washout period between treatment periods. After 14 days, significantly reduced RLS symptoms and improved sleep were observed in subjects with moderate-to-severe primary RLS while dose levels were well tolerated.

In a 12-week, multicenter, randomized, double-blind, placebo controlled phase III clinical trial, efficacy of gabapentin enacarbil $(1200 \mathrm{mg} /$ day orally at $5 \mathrm{PM})$ was evaluated in patients with primary RLS. Patients treated with gabapentin enacarbil showed an improved international RLS (IRLS) total score (-13.2) in contrast to placebo group (-8.8) at 2 weeks. On the investigator-rated CGI (Clinical Global Impression), significantly more gabapentin enacarbil-treated patients (76.1\%) responded than placebo (38.9\%). At the end of study more than $50 \%$ of gabapentin enacarbil-treated patients showed no sign of RLS over the 24-hour assessment period compared with $18 \%$ placebo patients. ${ }^{63,64}$

Long-term safety and efficacy of gabapentin enacarbil was evaluated in a second multicenter, placebo-controlled clinical trial involving 327 patients with primary moderateto-severe RLS symptoms. ${ }^{65}$ Patients received gabapentin enacarbil (1200 mg/day orally) at 5 PM for 24 weeks in a single-blind phase of trial. The initial 24 weeks phase was completed with 221 patients, out of which 194 (88\%) 
responded either "much improved" or "very much improved" CGI scores. These patients were further entered into a 12-week randomized, double-blind phase. Patients were given gabapentin enacarbil for either 12 weeks (1200 mg/day po) or for 2 weeks ( $600 \mathrm{mg} /$ day po) and then placebo for 10 weeks. For the extended trial, the primary end-point was number of patients who relapsed or had worsening symptoms. Gabapentin enacarbil treated group showed a statistically significant lower proportion of relapses than placebo, $9 \%$ versus $23 \%$ respectively. A third phase III trial evaluated the safety and efficacy of 600 and $1200 \mathrm{mg} /$ day over 12 weeks. ${ }^{66}$ Both dose groups of gabapentin enacarbil resulted in significantly improved IRLS and CGI scores than with placebo.

In addition to RLS, other indications are being investigated for gabapentin enacarbil. ${ }^{67}$ The additional indications include post-herpetic neuralgia, painful diabetic neuropathy, and migraine prophylaxis. Recently, top-line results were presented from a phase II clinical study of placebo, 1200, 2400 or $3600 \mathrm{mg} /$ day of gabapentin enacarbil dosed twice a day for treatment of post-herpetic neuralgia. All doses demonstrated statistically significant improvements over placebo on the change from baseline to the end of maintenance treatment in the 24-hour average pain intensity score. This 14-week, doubleblind, placebo-controlled study enrolled 376 subjects experiencing pain for at least 3 months following healing of herpes zoster skin rash. Gabapentin enacarbil was generally well tolerated at all doses, and the most common adverse events were dizziness and somnolence, and most were mild or moderate.

\section{Conclusions}

RLS is a sleep-related movement disorder which involves an undesirable sensation to move the legs, which improves with activity. It is typically worse in the evenings and nights. Dopaminergic agents are currently the most commonly prescribed therapy. Long-term use of dopaminergic drugs may cause augmentation or other side effects such as leg edema, dizziness, and nausea. Gabapentin, an analog of GABA, is an anticonvulsant/analgesic agent. Gabapentin is only mildly effective in relieving RLS symptoms, perhaps because of poor absorption from the gastrointestinal tract. Gabapentin enacarbil, a prodrug of gabapentin, is designed to enhance gastrointestinal absorption and hence enhance bioavailability of gabapentin. Clinical trials have shown gabapentin enacarbil to be a safe and effective drug for RLS. An application for approval of gabapentin enacarbil for treatment of RLS is currently pending with FDA for approval, and additional clinical indications are being pursued, including neuropathic pain. The addition of one more therapeutic option to the RLS drug armamentarium would provide more options to physicians dealing with RLS patients with refractory symptoms.

\section{Disclosures}

The authors disclose no conflicts of interest.

\section{References}

1. Nichols DA, Allen RP, Grauke JH, et al. Restless legs syndrome symptoms in primary care: a prevalence study. Arch Intern Med. 2003;163:2323-2329.

2. Allen RP, Walters AS, Montplaisir J, et al. Restless legs syndrome prevalence and impact: REST general population study. Arch Intern Med. 2005;165:1286-1292.

3. Högl B, Kiechl S, Willeit J, et al. Restless legs syndrome: a communitybased study of prevalence, severity, and risk factors. Neurology. 2005;64:1920-1924.

4. Allen R, Picchiertti D, Hening W, et al. Restless leg syndrome: diagnostic criteria, special considerations, and epidemiology. A report from the restless legs syndrome diagnosis and epidemiology workshop at the National Institute of Health. Sleep Med. 2003;4:101-119.

5. Yee B, Killick R. Restless legs Syndrome. Australian Family Physician. 2009:38:296-300.

6. Trenkwalder C, Heninig WA, Montagna P, et al. Treatment of restless legs syndrome: An evidence-based review and implications for clinical practice. Mov Disord. 2008;23:2267-2302.

7. Pfizer Inc. Neurontin Prescribing Information. 2007 January 2007; http:// www.pfizer.com/files/products/uspi_neurontin.pdf. Accessed February 16, 2010 .

8. McLean MJ. Gabapentin in the management of convulsive disorders. Epilepsia. 1999;40 Suppl 6:S39-S50; discussion S73-S74.

9. Anhut H, Ashman P, Feuerstein TJ, et al. Gabapentin (Neurontin) as add-on therapy in patients with partial seizures:a double-blind, placebocontrolled study. The International Gabapentin Study Group. Epilepsia. 1994;35:795-801.

10. IVAX launches gabapentin tablets. IVAX Corp Press Release August 18, 2004.

11. Thorp ML, Morris CD, Bagby SP. A crossover study of gabapentin in treatment of restless legs syndrome among hemodialysis patients. Am J Kidney Dis. 2001;38:104-108.

12. Micozkadioglu H, Ozdemir FN, Kut A, Sezer S, Saatci U, Haberal M. Gabapentin versus levodopa for the treatment of Restless Legs Syndrome in hemodialysis patients: an open-label study. Ren Fail. 2004;26:393-397.

13. Garcia-Borreguero D, Larrosa O, de la Llave Y, Verger K, Masramon X, Hernandez G. Treatment of restless legs syndrome with gabapentin: a double-blind, cross-over study. Neurology. 2002;59:1573-1579.

14. Happe S, Klosch G, Saletu B, Zeitlhofer J. Treatment of idiopathic restless legs syndrome (RLS) with gabapentin. Neurology. 2001;57: 1717-1719.

15. Happe S, Sauter C, Klosch G, Saletu B, Zeitlhofer J. Gabapentin versus ropinirole in the treatment of idiopathic restless legs syndrome. Neuropsychobiology. 2003;48:82-86.

16. Mellick GA, Mellick LB. Management of restless legs syndrome with gabapentin (Neurontin). Sleep. 1996;19:224-226.

17. Mellick LB, Mellick GA. Successful treatment of reflex sympathetic dystrophy with gabapentin. Am J Emerg Med. 1995;13:96.

18. Backonja M, Beydoun A, Edwards KR, et al. Gabapentin for the symptomatic treatment of painful neuropathy in patients with diabetes mellitus: a randomized controlled trial. JAMA. 1998;280:1831-1836.

19. Pollack MH, Matthews J, Scott EL. Gabapentin as a potential treatment for anxiety disorders. Am J Psychiatry. 1998;155:992-993.

20. Bockbrader HN, Breslin EM, Underwood BA, et al. Multiple-dose, dose-proportionality study of neurontin (gabapentin) in healthy volunteers. Epilepsia. 1996;37 Suppl 5:159. 
21. Gidal BE, DeCerce J, Bockbrader HN, et al. Gabapentin bioavailability: effect of dose and frequency of administration in adult patients with epilepsy. Epilepsy Res. 1998;31:91-99.

22. Gidal BE, Radulovic LL, Kruger S, et al. Inter- and intra-subject variability in gabapentin absorption and absolute bioavailability. Epilepsy Res. 2000;40:123-127.

23. Boyd RA, Turck D, Abel RB, et al. Effects of age and gender on singledose pharmacokinetics of gabapentin. Epilepsia. 1999;40:474-479.

24. Neurontin (gabapentin) capsule [package insert]. April 2009.

25. Stewart BH, Kugler AR, Thompson PR, et al. A saturable transport mechanism in the intestinal absorption of gabapentin is the underlying cause of the lack of proportionality between increasing dose and drug levels in plasma. Pharm Res. 1993;10:276-281.

26. Uchino H, Kanai Y, Kim do K, et al. Transport of amino acid-related compounds mediated by L-type amino acid transporter 1 (LAT1) insights into the mechanisms of substrate recognition. Mol Pharmacol. 2002;61:729-737.

27. Rice AS and Maton S. Postherpetic Neuralgia Study Group. Gabapentin in postherpetic neuralgia: a randomised, double blind, placebo controlled study. Pain. 2001;94:215-224.

28. Cundy KC, Branch R, Chernov-Rogan T, et al. XP13512 [( \pm$)-1-([(\alpha-$ Isobutanoyloxyethoxy)carbonyl] aminomethyl)-1-cyclohexane acetic acid], a novel gabapentin prodrug: I. Design, synthesis, enzymatic conversion to gabapentin, and transport by intestinal solute transporters J Pharmacol Exp Ther. 2004;311:315-323.

29. Richter A, Anton SE, Koch P, et al. The impact of reducing dose frequency on health outcomes. Clin Ther. 2003;25:2307-2335.

30. Rice AS, Maton S. Postherpetic Neuralgia Study Group. Gabapentin in postherpetic neuralgia: a randomised, double blind, placebo controlled study. Pain. 2001;94:215-224.

31. Enerson BE, Drewes LR. Molecular features, regulation and function of monocarboxylate transporters: implications for drug delivery. J Pharm Sci. 2003;92:1531-1544.

32. Wang H, Huang W, Fei YJ, et al. Human placental $\mathrm{Na}^{+}$-dependent multivitamin transporter: cloning, functional expression, gene structure and chromosomal localization. J Biol Chem. 1999;274:14875-14883.

33. Cundy KC, Sastry S, Luo W, et al. Clinical pharmacokinetics of XP13512, a novel transported prodrug of gabapentin. J Clin Pharmacol. 2008;48:1378-1388.

34. Merlino G, Serafini A, Young JJ, et al. Gabapentin enacarbil, a gabapentin prodrug for the treatment of the neurological symptoms associated with disorders such as restless legs syndrome. Curr Opin Investig Drugs. 2009;10:91-102.

35. Cundy KC, Annamalai T, Bu L, et al. XP13512 [( \pm$)-1-([(\alpha-$-Isobutanoyloxyethoxy) carbonyl] aminomethyl)-1-cyclohexane Acetic Acid], A Novel Gabapentin Prodrug: II. Improved Oral Bioavailability, Dose Proportionality, and Colonic Absorption Compared with Gabapentin in Rats and Monkeys. J Pharmacol Exp Ther. 2004;311:324-333.

36. Baillie JK, Power I. The mechanism of action of gabapentin in neuropathic pain. Curr Opin Investig Drugs. 2006;7(1):33-39.

37. Taylor CP, Gee NS, Su TZ, et al. A summary of mechanistic hypotheses of gabapentin pharmacology. Epilepsy Res. 1998;29:233-249.

38. Suman-Chauhan N, Webdale L, Hill DR, Woodruff GN. Characterisation of $\left[{ }^{3} \mathrm{H}\right]$ gabapentin binding to a novel site in rat brain: Homogenate binding studies. Eur J Pharmacol. 1993;244:293-301.

39. Jensen AA, Mosbacher J, Elg S, et al. The anticonvulsant gabapentin (Neurontin) does not act through $\gamma$-aminobutyric acid-B receptors. Mol Pharmacol. 2002;61:1377-1384.

40. Lanneau C, Green A, Hirst WD, et al. Gabapentin is not a $\mathrm{GABA}_{\mathrm{B}}$ receptor agonist. Neuropharmacology. 2001;41:965-975.

41. Ng GY, Bertrand S, Sullivan R, et al. $\gamma$-Aminobutyric acid type B receptors with specific heterodimer composition and postsynaptic actions in hippocampal neurons are targets of anticonvulsant gabapentin action. Mol Pharmacol. 2001;59:144-152.

42. Bertrand S, Ng GY, Purisai MG, et al. The anticonvulsant, antihyperalgesic agent gabapentin is an agonist at brain $\gamma$-aminobutyric acid type $B$ receptors negatively coupled to voltage-dependent calcium channels. J Pharmacol Exp Ther. 2001;298:15-24.
43. Bertrand S, Nouel D, Morin F, et al. Gabapentin actions on Kir3 currents and $\mathrm{N}$-type $\mathrm{Ca}^{2+}$ channels via GABAB receptors in hippocampal pyramidal cells. Synapse. 2003;50:95-109.

44. Mixcoatl-Zecuatl T, Medina-Santillan R, Reyes-Garcia G, et al. Effect of $\mathrm{K}^{+}$channel modulators on the antiallodynic effect of gabapentin. Eur J Pharmacol. 2004;484:201-208.

45. Lee C-H, Tsai T-S, Liou H-H. Gabapentin activates ROMK1 channels by a protein kinase A (PKA)-dependent mechanism. Br J Pharmacol. 2008;154:216-225.

46. Singh L, Field MJ, Ferris P, et al. The antiepileptic agent gabapentin (Neurontin) possesses anxiolytic-like and antinociceptive actions that are reversed by D-serine. Psychopharmacology (Berl). 1996;127:1-9.

47. Dissanayake VU, Gee NS, Brown JP, Woodruff GN. Spermine modulation of specific $[3 \mathrm{H}]$-gabapentin binding to the detergent solubilized porcine cerebral cortex $\alpha 2 \delta$ calcium channel subunit. Br J Pharmacol. 1997; 120:833-840.

48. Fink K, Dooley DJ, Meder WP, et al. Inhibition of neuronal $\mathrm{Ca}^{2+}$ influx by gabapentin and pregabalin in the human neocortex. Neuropharmacology. 2002;42:229-236

49. Chen SR, Eisenach JC, McCaslin PP, Pan HL. Synergistic effect between intrathecal non-NMDA antagonist and gabapentin on allodynia induced by spinal nerve ligation in rats. Anesthesiology. 2000;92:500-506.

50. Hayashida K, Obata H, Nakajima K, Eisenbach JC. Gabapentin acts within the locus coeruleus to alleviate neuropathic pain. Anesthesiology. 2008;109:1077-1084.

51. Taylor CP. Gabapentin. Mechanism of action. In: Levy RH, Mattson RH, Meldrum BS, Perucca E, editors. Antiepileptic Drugs, 5th ed. Philadelphia: Lippincott Williams \& Wilkins; 2002. p. 321-334.

52. Gee NS, Brown JP, Dissanayake VU, et al. The novel anticonvulsant drug, gabapentin (Neurontin), binds to the $\alpha_{2} \delta$ subunit of a calcium channel. J Biol Chem. 1996;271:5768-5776.

53. Hendrich J, Van Minh AT, Heblich F, et al. Pharmacological disruption of calcium channel trafficking by the $\alpha_{2} \delta$ ligand gabapentin. PNAS. 2008;105:3628-3633.

54. Lal R, Sukbuntherng J, Luo W, et al. Pharmacokinetics and tolerability of single escalating doses of gabapentin enacarbil: a randomizedsequence, double-blind, placebo-controlled crossover study in healthy volunteers. Clin Ther. 2009;31:1776-1786.

55. Canafax DM, Moors TL, Cundy KC. Single- and multi-dose phase I studies of XP13512, a transported prodrug of gabapentin, demonstrate safety, tolerability and dose-proportional gabapentin pharmacokinetics. Int Conf Mech Treatment Neuropathic Pain. 2004 Nov: 4-6.

56. Cundy K, Sastry CK, Luo W, et al. Clinical pharmacokinetics of XP13512: A novel transported prodrug of gabapentin. Neurology. 2008;70 Suppl 1:A293.

57. Cundy K, Sastry CK, Luo W, et al. Clinical pharmacokinetics of XP13512: A summary of four healthy volunteer studies. Sleep. 2008;31 Suppl A268: Abs 818.

58. Fenner LJ, Canafax DM, Moors TL, et al. A phase 1 randomized, cross over, single dose study of the safety, tolerability, and pharmacokinetics of XP13512 sustained released tablets vs Neurontin in healthy adult subjects. Int Conf Mech Treatment Neuropathic Pain. 2004: Nov 4-6.

59. Lal R, Sukbuntherng J, Luo W, et al. Clinical pharmacokinetic drug-interaction studies of XP13512, a novel transported prodrug of gabapentin, with naproxen and cimetidine [abstract]. Neurology. 2008; 70(11) Suppl 1:A295.

60. Lal R, Sukbuntherng J, Luo W, et al. Clinical pharmacokinetics of gabapentin after oral administration of XP13512/GSK1838262 tablets and naproxen in healthy adults. J Clin Pharmacol. 2008;48(9):1124.

61. Kushida C, Becker P, Perkins T, et al. XP13512 improves symptoms and sleep disturbance in RLS patients: Results of a 2-week, randomized, double blind, placebo controlled cross-over polysomnographic trial. Sleep. 2006;29:Suppl S:A278.

62. Kushida CA, Walters AS, Becker P, et al. A randomized, double-blind, placebo-controlled, crossover study of XP13512/GSK1838262 in the treatment of patients with primary restless legs syndrome. Sleep. 2009;32:159-168. 
63. Ellenbogen AL, Kushida CA, Becker PM, et al. XP13512/GSK1838262 $1200 \mathrm{mg}$ provides symptomatic relief in restless legs syndrome patients: A randomized, double-blind, placebo-controlled study. Mov Disord. 2008;23(1 Suppl S364):Abs 1113.

64. Becker P, Kushida C, Ellenbogen A, et al. XP13512 reduces restless legs syndrome symptoms and associated sleep impairment: Results of double blind, randomized, placebo-controlled study. Sleep. 2008;31 Suppl A268:Abs 817.
65. Xenoport and GlaxoSmithKline report positive top-line results of second phase III restless legs syndrome trial for XP13512/GSK1838262. XenoPort Inc. Press Release, Jan 15, 2008.

66. XenoPort and GlaxoSmithKline report positive top-line results of final pivotal trail of XP13512/GSK1838262 for restless legs syndrome. XenoPort Inc. Press Release, Feb 28, 2008.

67. www.xenoport.com.

\section{Publish your work in this journal}

Neuropsychiatric Disease and Treatment is an international, peerreviewed journal of clinical therapeutics and pharmacology focusing on concise rapid reporting of clinical or pre-clinical studies on a range of neuropsychiatric and neurological disorders. This journal is indexed on PubMed Central, the 'PsycINFO' database and CAS, and is the official

journal of The International Neuropsychiatric Association (INA). The manuscript management system is completely online and includes a very quick and fair peer-review system, which is all easy to use. Visit http://www.dovepress.com/testimonials.php to read real quotes from published authors.

Submit your manuscript here: http://www.dovepress.com/neuropsychiatric-disease-and-treatment-journal 